\title{
Osteocalcin and Calcium Homeostasis in Type I Diabetes: Effect of Vitamin D Bolus
}

\author{
Mohammed A. Abdel-Hafez, ${ }^{1, *}$ Dawlat E. Salem, ${ }^{1}$ Gamal Mohsen, ${ }^{1}$ \\ Fatma El-MougY, ${ }^{2}$ Nermin BAHgAT, ${ }^{2}$ Mohamed A. GAAFAR, ${ }^{3}$ \\ Khadiga EsHMAWY, ${ }^{3}$ and Hala GAMAL ${ }^{3}$ \\ ${ }^{1}$ Department of Biochemistry, ${ }^{2}$ Department of Chemical Pathology, and \\ ${ }^{3}$ Department of Internal Medicine, Faculty of Medicine, \\ Cairo University, Kasr El-Aini, Cairo, Egypt
}

(Received August 17, 1993)

\begin{abstract}
Summary This work was designed to clarify the influence of a vitamin $\mathrm{D}_{3}$ bolus on bone metabolic turnover as manifested by serum osteocalcin, calcium, and other parameters. Bone, like other tissues, in diabetics displays microangiopathy, particularly in the case of type I diabetes. Insulin-dependent diabetics (IDD) without retinopathy (Group I, $n=18$ ), with retinopathy (Group II, $n=16$ ), and healthy persons (Group III, $n=16$ ) were studied. Fasting and 2-h postprandial serum glucose, $\mathrm{Ca}^{2+}$ (total and ionized), albumin, alkaline phosphatase (ALP), osteocalcin $(\mathrm{OC})$, parathormone $(\mathrm{PTH}), 25(\mathrm{OH}) \mathrm{D}_{3}, 1,25(\mathrm{OH})_{2} \mathrm{D}_{3}$, and 24-h urinary calcium were evaluated. Diabetics were injected I.M. with $600,000 \mathrm{IU}$ of vitamin $\mathrm{D}_{3}$, and were maintained on their dietary and antidiabetic regimen. There was a significant decrease in serum $\mathrm{Ca}^{2+}$ (total and ionized), urinary calcium, $\mathrm{OC}, 1,25(\mathrm{OH})_{2} \mathrm{D}_{3}$ and serum albumin and significant increases in glucose and ALP in both diabetic groups compared with the control. Vitamin $\mathrm{D}_{3}$ injection in diabetics led to increase in plasma $25(\mathrm{OH}) \mathrm{D}_{3}$ and $1,25(\mathrm{OH})_{2} \mathrm{D}_{3}$ and decrease in $\mathrm{PTH}$ levels together with normalization of serum $\mathrm{Ca}^{2+}$ (total and ionized) and 24-h urinary calcium, ALP, and OC. This could be due to the specific action of vitamin $D_{3}$. The insignificant difference in calcium levels and its controlling hormones between complicated and uncomplicated diabetics suggests that development of angiopathy neither exaggerates osteopathy nor impairs the osteogenic effect of vitamin $D_{3}$. Hepatic and renal metabolism of the latter were intact. Vitamin $\mathrm{D}_{3}$ injection could ameliorate diabetic hyperglycaemia and improve hypoalbuminaemia.
\end{abstract}

*To whom correspondence should be addressed. 
Key Words: calcium, diabetes mellitus, $1,25(\mathrm{OH})_{2} \mathrm{D}_{3}$, osteocalcin, osteopenia

Osteocalcin (OC) or bone GLA protein is a small 49-amino acid, noncollagenous, vitamin $\mathrm{K}$-dependent protein synthesized by osteoblasts [1]. It binds to hydroxyapatite and accumulates in the bone matrix. Nanomolar concentrations of OC are released into the blood, and its measurement in serum or plasma is a convenient method for the study of bone turnover [2]. $1,25(\mathrm{OH})_{2} \mathrm{D}_{3}$ stimulates synthesis of $\mathrm{OC}$ [3], and insulin [4] and growth factors [5] also promote bone formation and $\mathrm{OC}$ synthesis. On the other hand, modulators of bone resorption also affect OC synthesis; e.g., PTH decreases it.

A growing body of evidence indicates some reduction of bone mass (osteopenia) in many people with diabetes mellitus, both type I and type II. Multiple factors may be involved in the development of disturbed calcium homeostasis in diabetes; these are hyperglycaemia [6], insulin deficiency [7], increased plasma prostaglandins [8], reduced somatomedins [9], phosphate and magnesium depletion due to increased urinary loss [10], adrenal hyperfunction [11], and disturbed production of vitamin D metabolites [12]. Microangiopathy may be responsible for defective tissue perfusion with subsequent deleterious metabolic effects. This study was planned to evaluate serum calcium and related factors in type I diabetes as well as to examine the effect of microangiopathy on such parameters. Influence of vitamin D bolus was also studied to assess its value as additive therapy.

\section{SUBJECTS AND METHODS}

Subjects. This study was performed on 34 patients and 16 healthy controls. The patients were selected from the medical wards of Cairo University Hospital.

The subjects were divided into 3 groups: Group I ( $n=18)$ : Insulin-dependent diabetes mellitus (IDDM), with controlled hyperglycaemia and without evidence of vascular or other diabetic complications. Their age was $21 \pm 4.68$ years $( \pm S D)$. Group II $(n=16)$ : IDDM with uncontrolled hyperglycaemia and diabetic retinopathy. Other diabetic complications were excluded. Their age was $34.06 \pm 6.68$ years. Group III $(n=16)$ : Healthy subjects as a control group. Their age was $27.25 \pm 7.21$ years.

Sampling and analytical methods. Venous blood samples were taken after an overnight fast, and $2 \mathrm{~h}$ after an oral glucose load $(1.0 \mathrm{~g} / \mathrm{kg}$ body weight $)$. Intramuscular injection of 600,000 IU of vitamin $\mathrm{D}_{3}$ was done (Devarol, Memphis Co., Cairo, Egypt). Another injection was repeated after 1 week. Fasting and 2-h postprandial samples were taken 1 week later. Serum glucose, total calcium, albumin, and alkaline phosphatase were measured in fresh samples by ordinary colorimetric methods using kits produced by Biomerieux, Cedex, France. Ionized calcium was measured with an ICAI Radiometer (Copenhagen, Denmark) [13]. 
Sera for determination of $\mathrm{OC}, \mathrm{PTH}$, and $25(\mathrm{OH}) \mathrm{D}_{3}$ were kept frozen at $-20^{\circ} \mathrm{C}$ till the time of assay. Both osteocalcin [14] and $25(\mathrm{OH}) \mathrm{D}_{3}[15]$ were measured by the double antibody technique of radioimmunoassay using the corresponding ${ }^{125} \mathrm{I}$ labelled antigens. PTH (intact) was measured by use of ${ }^{125}$ I-labelled goat antibody specific for PTH 1-34 [16]. Determination of plasma $1,25(\mathrm{OH})_{2} \mathrm{D}_{3}$ was preceded by chromatographic cleaning-up by microcolumns packed with octadecyl silane $\left(\mathrm{C}_{18}\right) \mathrm{OH}$ (Millipore, Milford, MA). The technique followed was the radioreceptor assay, and the receptors were prepared from calf thymus by the manufacturer. The tracer used was $1,25(\mathrm{OH})_{2}\left\{{ }^{3} \mathrm{H}-26,27\right\} \mathrm{D}_{3}$ [17]. The kits for the assay of OC, PTH, $25(\mathrm{OH}) \mathrm{D}_{3}$ and $1,25(\mathrm{OH})_{2} \mathrm{D}_{3}$ were produced by Incaster Corp., Stillwater, MN.

The data obtained were statistically analyzed according to Student's $t$-test for unpaired and paired data. Correlation coefficient $(r)$ was calculated among the investigated parameters.

\section{RESULTS}

In both diabetic Groups (I and II) serum calcium (total and ionized) and the 24-h urinary calcium levels were significantly reduced compared with those of the control group. They were significantly elevated to almost the level of the controls after vitamin D injection (Table 1). The same pattern was observed for osteocalcin (OC) and albumin i.e., their serum levels were decreased in Groups I and II before vitamin D injection and significantly elevated after the vitamin D bolus (Tables 1, 2).

ALP activity was significantly higher in diabetics than in controls before the vitamin $\mathrm{D}$ injection, and was corrected after vitamin $\mathrm{D}$ administration. ALP and total calcium levels were significantly positively correlated $(r=0.624, p<0.01)$ in controlled diabetics. $1,25(\mathrm{OH})_{2} \mathrm{D}_{3}$ was significantly lower in complicated diabetics than in the controls, but vitamin $\mathrm{D}$ administration led to a significant increase in both $25(\mathrm{OH}) \mathrm{D}_{3}$ and $1,25(\mathrm{OH})_{2} \mathrm{D}_{3}$ levels $(p<0.001)$ and to a decrease in the PTH level in both diabetic groups compared with the controls. Meanwhile, a significant positive correlation was observed between $1,25(\mathrm{OH})_{2} \mathrm{D}_{3}$ and $\mathrm{OC}$ in the complicated diabetic patients (Group II) $(r=0.523, p<0.001)$ after vitamin D injection.

Serum PTH was not altered significantly in Groups I and II vs. Group III before vitamin bolus administration. Its level was significantly reduced thereafter.

Serum glucose levels were significantly $(p<0.05)$ decreased after vitamin D administration in both diabetic groups (Table 3 ).

\section{DISCUSSION}

Insulin-dependent diabetes mellitus (IDDM) is frequently associated with osteoporosis. Impaired bone formation due to osteoblast deficit has been proposed as a cause of diabetic osteopenia. Chronic insulin deficiency may well prove to be a key factor in the development of diabetic osteopenia [7]. Hence, we chose this 

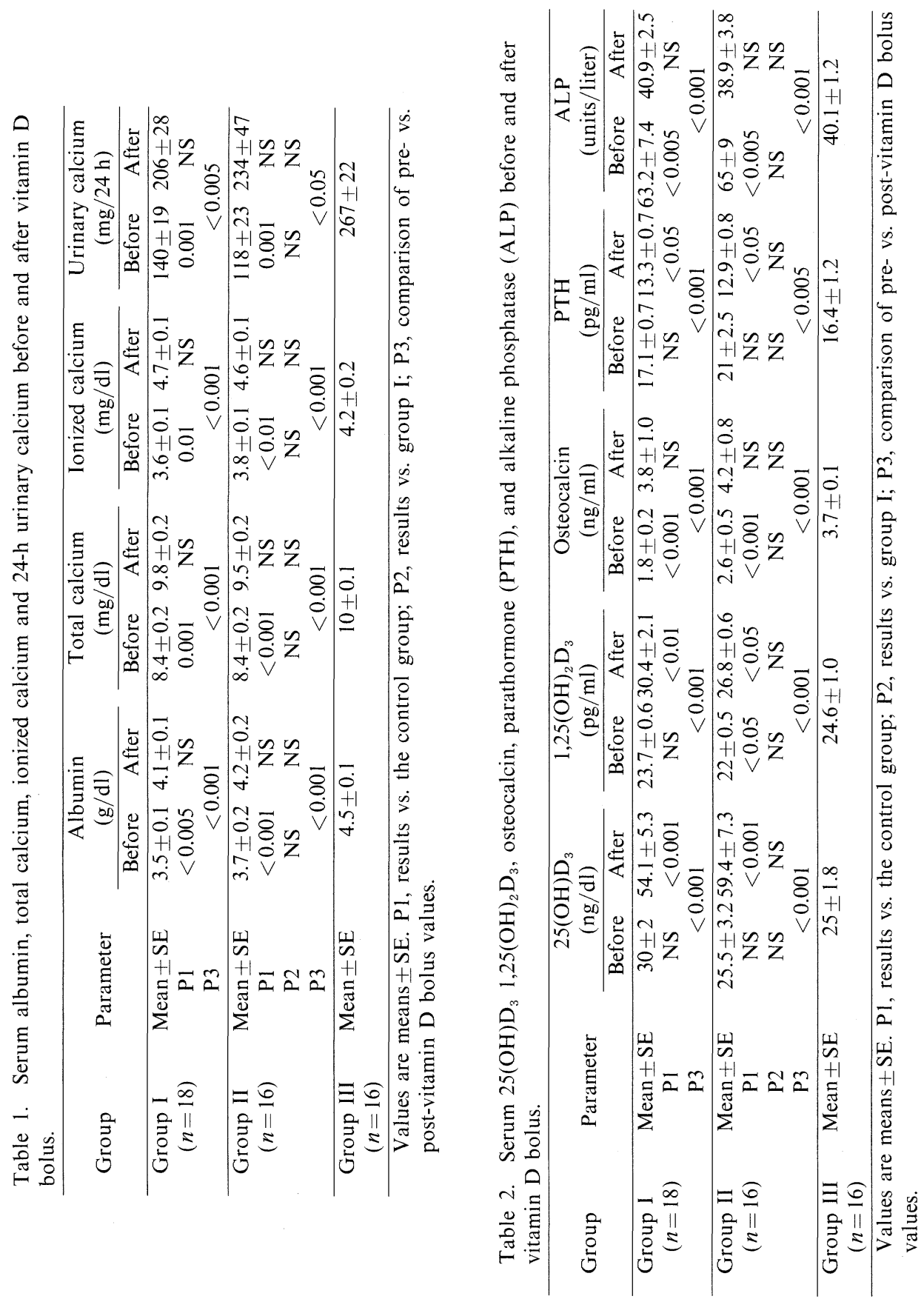
Table 3. Serum glucose $(\mathrm{mg} / \mathrm{dl})$, fasting and postprandial, before and after vitamin D bolus in diabetics.

\begin{tabular}{|c|c|c|c|c|c|}
\hline \multirow{2}{*}{ Group } & \multirow{2}{*}{ Parameter } & \multicolumn{2}{|c|}{ Before } & \multicolumn{2}{|c|}{ After } \\
\hline & & Fasting & Postprandial & Fasting & Postprandial \\
\hline \multirow{3}{*}{$\begin{array}{l}\text { Group I } \\
\quad(n=18)\end{array}$} & Mean $\pm \mathrm{SE}$ & $111 \pm 5$ & $159 \pm 5$ & $111 \pm 4$ & $137 \pm 6$ \\
\hline & $\mathrm{Pl}$ & $<0.001$ & $<0.001$ & $<0.001$ & $<0.001$ \\
\hline & P3 & & & NS & $<0.05$ \\
\hline \multirow{4}{*}{$\begin{array}{l}\text { Group II } \\
\quad(n=16)\end{array}$} & Mean $\pm S E$ & $228 \pm 36$ & $291 \pm 28$ & $179 \pm 23$ & $223 \pm 30$ \\
\hline & P1 & $<0.001$ & $<0.001$ & $<0.001$ & $<0.001$ \\
\hline & $\mathrm{P} 2$ & $<0.001$ & $<0.001$ & $<0.001$ & $<0.001$ \\
\hline & P3 & & & $<0.05$ & $<0.025$ \\
\hline $\begin{array}{r}\text { Group III } \\
\quad(n=16)\end{array}$ & Mean $\pm S E$ & $86 \pm 4$ & $115 \pm 23$ & $81 \pm 3.1$ & $104 \pm 3.5$ \\
\hline
\end{tabular}

type of diabetes to study.

Our results demonstrated an insignificant increase in $25(\mathrm{OH}) \mathrm{D}_{3}$ in diabetic groups compared with the control and a significantly lower level of $1,25(\mathrm{OH})_{2} \mathrm{D}_{3}$ in complicated diabetics and an insignificant alteration in controlled diabetics compared with healthy controls. This may indicate that insulinopenia is the mechanism by which circulating $1,25(\mathrm{OH})_{2} \mathrm{D}_{3}$ is reduced and suggests a relationship between $1,25(\mathrm{OH})_{2} \mathrm{D}_{3}$ and diabetic metabolic control, as indicated earlier [18]. Moreover, in a previous study a decreased activity of $1 \alpha$-hydroxylase was suggested $[19,20]$. Also, reduced circulating vitamin D-binding protein reported in diabetes may be responsible for inhibition of the enzyme [21].

Elevated serum ALP activity has been found in diabetics. Our findings of low serum $\mathrm{OC}$, total and ionized calcium levels before vitamin $\mathrm{D}$ administration and the normalization of ALP together with its positive correlation with $\mathrm{Ca}^{2+}$ after vitamin D administration suggest a bone source of the originally elevated ALP. Before vitamin D administration PTH levels showed insignificant changes in the two diabetic groups compared with the control. This agrees with some previous reports [22] and is contradictory to others [7]. The observed significant reduction in serum OC in diabetics compared with the control supports previous reports [23]. In diabetic patients a severe reduction in the number and/or function of osteoblasts along with decreased osteoid surface, mineral apposition rate, and plasma OC was reported [24].

Serum calcium, total and ionized, and 24-h urinary calcium were decreased in both diabetic groups compared with their levels in the control group. No significant difference was observed between the diabetic groups. The lower serum ionized calcium levels may be attributed to increased calcium binding to plasma proteins [25]. The osteoblast deficit, demonstrated in the present study by low levels of OC, may be a contributing factor. On the other hand, intestinal absorption of calcium has been shown to be increased [26] or normal [22] in diabetic subjects. The 
finding of an insulin-reversible increase in intestinal absorption of calcium in insulinopenic diabetes was interpreted as a compensatory mechanism for the marked renal calcium loss observed in these patients.

After vitamin D supplementation, normalization of serum total and ionized calcium, 24-h urinary calcium, serum OC, and ALP together with decreased serum PTH was observed. This may indicate improvement of bone turnover in diabetics. The associated increase in $1,25(\mathrm{OH})_{2} \mathrm{D}_{3}$ and the positive correlation between $\mathrm{OC}$ and $1,25(\mathrm{OH})_{2} \mathrm{D}_{3}$ encountered in Group II of complicated diabetics after vitamin $\mathrm{D}$ supplementation support this explanation. The reduced levels of serum albumin in diabetics could be due to defective hepatic synthesis or associated diabetic albuminuria. Decreased serum albumin possibly explains parallel changes in serum calcium. The significant increase in serum albumin after vitamin D bolus suggests an enhancing effect of the latter on albumin synthesis, probably by a mechanism similar to the effect of this vitamin on calbindin (calcium binding protein) and vitamin D-binding protein genes [27].

Lowering of blood glucose level observed in diabetics (Groups I and II) after vitamin D administration could be attributed to increased plasma insulin. Studies of Tanaka et al. showed a direct action of vitamin D metabolites on pancreatic B-cell function [28]. Rise of serum C-peptide and improvement of peripheral glucose utilization after vitamin $\mathrm{D}$ administration was also reported in our laboratory [29]. Meanwhile, the significant elevation of the levels of $25(\mathrm{OH}) \mathrm{D}_{3}$ and $1,25(\mathrm{OH})_{2} \mathrm{D}_{3}$ in Groups I and II after vitamin $\mathrm{D}_{3}$ administration may be due to improvement of glucose tolerance and increased insulin secretion, which lead to improved renal $1 \alpha$-hydroxylase function.

In conclusion, a beneficial action of vitamin $\mathrm{D}$ on bone turnover may be suggested from this study, which action leads to normalization of serum calcium, PTH, ALP, and OC. Development of microangiopathy is not necessarily exaggerating diabetic changes in bones nor delaying the effect of vitamin $\mathrm{D}$ on bone turnover. It is noteworthy to stress that diabetics may have a reduced plasma $1,25(\mathrm{OH})_{2} \mathrm{D}_{3}$ concentration, especially if the disease is poorly controlled. Plasma $1,25(\mathrm{OH})_{2} \mathrm{D}_{3}$ levels should be periodically checked; and if they are found to be low, vitamin D supplementation could be of benefit.

\section{REFERENCES}

1. Price, P.A. (1985): Vitamin K dependent formation of bone Gla-protein (osteocalcin) and its function. Vitam. Horm., 42, 95-108.

2. Tarallo, P., Henny, J., Fournier, B., and Siest, G. (1990): Plasma osteocalcin: Biological variations and reference limits. Scand. J. Clin. Lab. Invest., 560, 649-655.

3. Rico, H., Hernandez, E.R., Cabranes, J.A., and Castresany, F.G. (1989): Suggestion of a deficient osteoblastic function in diabetes mellitus. The possible cause of osteopenia in diabetics. Calif. Tissue Int., 45, 71-73.

4. Lian, J.B., Couttes, M.C., and Canalis, E. (1985): Studies of hormonal regulation of osteocalcin synthesis in cultured fetal rat calvaria. J. Biol. Chem., 260, 8706-8710.

J. Clin. Biochem. Nutr. 
5. Canalis, E., and Jian, J.B. (1988): Effects of bone associated growth factors on DNA, collagen and osteocalcin synthesis in cultured fetal rat calvaria. Bone, 9, 243-246.

6. McNair, P., Madsbad, S., Christensen, M.S., Faber, O.K., Binder, C., and Transbol, I. (1979): Bone mineral loss in insulin treated diabetes mellitus: Studies on pathogenesis. Acta Endocrinol., 90, 463-472.

7. Hahn, T.J., Downing, S.J., and Phang, J.M. (1971): Insulin effect on amino acid transport in bone dependence on protein synthesis and Na. Am. J. Physiol., 220, 1717-1723.

8. Chase, H.P., Williams, R.L., and Dupont, J. (1979): Increased prostaglandin synthesis in childhood diabetes mellitus. J. Pediatr., 94, 185-189.

9. Phillips, L.S., and Orawski, T. (1977): Nutrition and somatomedin. Diabetes, 26, 864-869.

10. Hough, S., and Avioli, L.V. (1981): Alterations of bone and mineral metabolism in diabetes, in Recent Advances in Diabetes, ed. by Mattrass, M. and Santiago, J.V., Churchill, Livingstone, New York, pp. 223-229.

11. Stancakova, A., Merstenova, E., Vajo, J., and Valkova, M. (1978): The excretion of free cortisol, cortisol sulfate and cortisone sulfate in peripheral vascular disease, diabetes mellitus and hyperthyroidism. Horm. Metabol. Res., 10, 539-544.

12. Hough, S. (1987): Alterations of bone and mineral metabolism in diabetes mellitus. Start II, Clinical studies in 206 patients with type I diabetes mellitus. S. Afr. Med. J., 72, 120-126.

13. Fogh-Andersen, N. (1981): Ionized calcium analyzer with a built-in $\mathrm{pH}$ correlation. Clin. Chem., 27, 1264-1267.

14. Price, P.A., Parhtemore, J.B., and Deftos, L.J. (1980): New biochemical marker for bone metabolism: Measurement by radioimmunoassay of bone Gla protein in the plasma of normal subjects and patients with bone disease. J. Clin. Invest., 66, 878-883.

15. Clemens, T.L. (1986): Vitamin D: Recent advances in basic research and clinical assay methodology. J. Clin. Immunol., 9, 183.

16. Christensen, M.S. (1979): Radioimmunoassay of human parathyroid hormone: A review with special reference to hyperparathyroidism in renal disease. Dan. Med. Bull., 16, 157-174.

17. Hollis, B.W. (1986): Assay of circulating, 1,25-dihydroxy vitamin D involving novel singlecartridge extraction and purification procedure. Clin. Chem., 32, 2060.

18. Fogh-Anderson, N., McNain, P., and Moller-Petersen, J. (1983): Lowered serum ionized calcium in insulin-treated diabetic subjects. Scand. J. Clin. Lab. Invest., 43, 93-97.

19. Spener, M.E., Khalil, M., and Tobiassen, O. (1980): Experimental diabetes in the rat causes an insulin reversible decrease in renal 25 hydroxy vitamin $D_{3} 1-\alpha$ hydroxylase activity. Endocrinology, 107, 300-305.

20. Wongsurawat, N., and Armbrchet, H.J. (1991): Calcitonin stimulates 1,25 dihydroxy vitamin D production in diabetic rat kidney. Metabolism, 40, 4-5.

21. Nyomba, B.L., Bouillon, R., Lissen, W., Van Baelen, H., and De Moor, P. (1985): 1,25 dihydroxy vitamin $\mathrm{D}$ and vitamin D-dependent protein are both decreased in streptozocin diabetic rats. Endocrinology, 116, 2483-2488.

22. Monnier, L., Colette, C., Aguierre, L., Sany, C., and Moronze, J. (1978): Intestinal and neural handling of calcium in human diabetes mellitus. Eur. J. Clin. Invest., 8, 225-231.

23. Ishida, H., Seino, Y., Taminato, T., Usami, M., Takeshita, N., Seino, Y., Tsutsumi, C., Moriuchi, S., Akiyama, Y., and Hara, K. (1988): Circulating levels and bone contents of bone carboxyglutamic acid-containing protein are decreased in streptozocin-induced diabetes. Diabetes, 37, 702-706.

24. Verhaeghe, J., Suiker, A.M.H., Nyomba, B.L., Visser, W.J., Einhorn, T.A., Dequeker, J., and Bouillon, R. (1989): Bone mineral homeostasis in spontaneously diabetic BB rats. II: Impaired bone turnover and decreased osteocalcin synthesis. Endocrinology, 124, 573-582.

25. Jasinski, K., Admski, A., and Smarsz, L. (1968): Plasma calcium fraction in diabetes mellitus. Pol. Med. J., 7, 1033.

26. Granner, D.K. (1990): Hormones that regulate calcium, in Harper's Biochemistry (22nd ed.), ed. by Murray, R.K., Granner, D.K., Mayes, P.A., and Rodwell, V.W., Appleton Lange, Connecticut, San Mateo, California, pp. 492-498. 
27. Norman, A.W., Roth, J., and Orci, L. (1982): The vitamin D endocrine system: Steroid metabolism, hormone receptors and biological response (calcium binding proteins). Endocr. Rev., 3, 331-366.

28. Tanaka, Y., Seino, Y., and Ishida, M. (1984): Effects of vitamin $D_{3}$ on pancreatic secretion of insulin and somatostatin. Acta Endocrinol., 105, 528-533.

29. Abdel-Hafez, M.A., Abdel-Ghany, N., Osman, A., and Naguib, S.M. (1989): Effect of cholecalciferol administration of diabetic hyperglycaemia. Bull. Egypt. Soc. Physiol. Sci., 9, $237-252$. 